\title{
ОСОБЛИВОСТІ ВПРОВАДЖЕННЯ ЕЛЕМЕНТІВ ДИСТАНЦЙНОГО НАВЧАННЯ У ПРОЦЕС СОЦІАЛЬНО-ГУМАНІТАРНОӤ ПІДГОТОВКИ МАГІСТРІВ ПРИРОДНИЧИХ СПЕЦІАЛЬНОСТЕЙ
}

\section{Н. В. Попенко}

Кременчуцький національний університет імені Михайла Остроградського

вул. Першотравнева, 20, м. Кременчук, 39600, Україна. E-mail:popenko_nata @ukr.net

Обгрунтовано особливості впровадження елементів дистанційного навчання у процес соціальногуманітарної підготовки магістрів природничих спеціальностей. Визначено основні фактори, що обумовлюють необхідність впровадження дистанційного навчання у процес підготовки магістрів природничого спрямування: зміна стилю навчання в магістратурі; поглиблення інтеграції навчання з науково-дослідною діяльністю; зміна способу життя майбутніх магістрів. Виділено основні принципи побудови та впровадження елементів дистанційних навчальних курсів в освітній процес підготовки магістрів, а саме: вільний вибір майбутнім магістром професійно-освітньої траєкторії; створення умов для самореалізації майбутнього магістра у творчій та дослідницькій діяльності; актуалізація і врахування соціально-професійного досвіду майбутнього магістра.

Ключові слова: освітній процес, дистанційне навчання, магістри природничих спеціальностей, соціальногуманітарна підготовка.

\section{ОСОБЕННОСТИ ВНЕДРЕНИЯ ЭЛЕМЕНТОВ ДИСТАНЦИОННОГО ОБУЧЕНИЯ В ПРОЦЕСС СОЦИАЛЬНО-ГУМАНИТАРНОЙ ПОДГОТОВКИ МАГИСТРОВ ЕСТЕСТВЕННЫХ СПЕЦИАЛЬНОСТЕЙ}

\section{Н. В. Попенко}

Кременчугский национальный университет имени Михаила Остроградского

ул. Первомайская, 20, г. Кременчуг, 39600, Украина. E-mail: popenko_nata@ukr.net

Обоснованы особенности внедрения элементов дистанционного обучения в процесс социальногуманитарной подготовки магистров естественных специальностей. Определены основные факторы, которые обусловливают необходимость внедрения дистанционного обучения в процесс подготовки магистров естественного направления: смена стиля обучения в магистратуре; углубление интеграции обучения с научноисследовательской деятельностью; смена стиля жизни будущих магистров. Выделены основные принципы построения и внедрения элементов дистанционных курсов в образовательный процесс подготовки магистров, а именно: свободный выбор будущими магистрами профессионально-образовательной траектории, создание условий для самореализации будущего магистра в творческой и исследовательской деятельности, актуализация и учет социально-профессионального опыта будущего магистра.

Ключевые слова: образовательный процесс, дистанционное обучение, магистры естественных специальностей социально-гуманитарная подготовка.

АКТУАЛЬНІСТЬ РОБОТИ. Зміни, що відбуваються сьогодні в суспільстві, вимагають адекватної трансформації системи освіти, а саме: забезпечення можливості навчатися протягом усього життя, надання всім громадянам рівних можливостей доступу до отримання освіти завдяки зняттю вікових, соціальних та організаційних обмежень, можливості формування й реалізації індивідуальної освітньої траєкторії для кожного майбутнього фахівця 3 урахуванням його психофізіологічних особливостей, уподобань, інтересів та здібностей, можливості обирати певні навчальні курси та зручний для суб'єкта навчання час. Сучасна модернізація вищої освіти стимулюється соціальним замовленням суспільства, а тому ставить нові вимоги до рівня підготовки майбутніх фахівців, а саме: уміння знаходити, аналізувати і систематизувати важливу інформацію, розвиток критичного мислення, самостійна творча діяльність. Здобувачам вищої освіти необхідно сьогодні навчитися працювати $з$ великим обсягом інформації: розуміти основний смисл того, що вони вивчають, спиратися на факти, узагальнювати відомий матеріал та робити обгрунтовані висновки. Тому посилюється інформатизація освіти, відбувається включення до системи освіти інформаційного середовища і залучення Інтернет-ресурсів. Відбувається зміна парадигми освіти
- значна роль надається методам активного пізнання, самоосвіті, дистанційному навчанню (ДН).

Про активний розвиток ДН свідчить низка нормативних документів та положень законодавства України - Національній доктрині розвитку освіти України у XXI столітті (2013), Законах України «Про освіту» (2017), «Про вищу освіту» (2014), Державній програмі «Освіта» (Україна XXI століття) (1993), «Концепції розвитку дистанційної освіти в Україні» (2000), «Положенні про дистанційне навчання» (2013).

На основі узагальнення результатів аналізу літературних джерел ми виділили праці як вітчизняних, так і зарубіжних вчених, що викликають особливий інтерес та присвячені питанням теорії і практики ДН, зокрема: змісту, розвитку та науковому забезпеченню дистанційної освіти (В. Биков, М. Михальченко, Л. Лещенко, П. Стефаненко); організаційнопедагогічним основам дистанційної освіти, організації ДН в післядипломній освіті (Н. Жевакіна, Н. Корсунська, В. Олійник, П. Таланчук, та інші); використання Інтернету в сучасному суспільстві, психолого-педагогічні аспекти і технології створення дистанційних курсів (Н. Болюбаш, В. Кухаренко, Т. Олійник, В. Рибалко, та інші); можливостям та перспективам ДН у закладах вищої освіти (3ВО) 
України та за кордоном (Р. Гуревич, В. Жулькевська, К. Корсак, Б. Шуневич та інші).

Переважна більшість вчених у своїх наукових працях підкреслюють необхідність впровадження ДН в освітній процес ЗВО. Однак, питання впровадження ДН у процес соціально-гуманітарної підготовки магістрів природничих спеціальностей, на нашу думку, досліджено не достатньо і потребує додаткового вивчення та розробки.

Мета пропонованої статті полягає у визначенні та обгрунтуванні особливостей впровадження елементів ДН в освітній процес магістрів природничого спрямування.

МАТЕРІАЛ I РЕЗУЛЬТАТИ ДОСЛІДЖЕНЬ. Аналіз науково-педагогічних досліджень свідчить, що різні вчені по-різному визначають ДН, але всі вони спільні в тому, що у визначення дистанційного навчання входять такі три компоненти: відкрите навчання, комп'ютерне навчання, комп'ютерна система комунікацій (Інтернет) [1].

Основу освітнього процесу при ДН складає цілеспрямована і контрольована інтенсивна самостійна робота студента, який може навчатися в зручному для себе місці, за індивідуальним розкладом, маючи при собі комплект спеціальних засобів навчання і погоджену можливість контакту з викладачем. Дистанційні форми навчання надають широкі можливості при розробці навчальних програм, орієнтованих на активізацію пізнавальної діяльності осіб, що навчаються, підготовки студентів до творчої самостійної роботи, реалізації ідеї індивідуального та диференційованого підходу в процесі навчання [2]. В Україні дистанційне навчання перебуває на етапі активного становлення, вивчається світовий досвід у галузі ДН, розробляється відповідна теоретична база, створюються центри ДН, накопичується практичний досвід. Розуміючи важливість процесу розвитку ДН, робоча група Міністерства освіти і науки України (МОНУ) розробила Положення про дистанційне навчання [3]. Положення визначає основні, визначальні принципи побудови ДН у ЗВО.

Розглянемо актуальні для нашого дослідження аспекти Положення:

- дистанційна форма навчання 3 прийняттям Положення нарешті стала «не експериментальною», а повноцінною окремою формою навчання;

- чітко визначено можливу сферу застосування дистанційного навчання в різних закладах освіти;

- передбачено гнучкі умови впровадження дистанційного навчання як окремої форми і дистанційних технологій в освітньому процесі за всіма іншими формами навчання;

- передбачено можливість дистанційного навчання іноземців, що вкрай необхідно для участі українських 3ВО у повноцінному конкурентному світовому освітньому середовищі. Це потребує повноцінних навчальних матеріалів іноземними мовами, насамперед англійською [4].

Як вже було зазначено, основною формою організації освітнього процесу за дистанційною формою $\epsilon$ самостійна робота. Крім того, у ЗВО під час організації освітнього процесу за будь-якою формою навчання можна використовувати технології диста- нційного навчання для навчально-методичного забезпечення самостійної роботи, контрольних заходів, а також і під час занять. Освітній процес організовується відповідно до освітніх програм та затверджених навчальних планів з урахуванням їх адаптації до ДН.

Проаналізуємо та визначимо актуальність та особливості впровадження елементів ДН у процес професійної підготовки магістрів природничих спеціальностей та їі соціально-гуманітарної складової.

Перехід до багаторівневої підготовки фахівців у ЗВО змінює не лише підходи до організації освітнього процесу, а і принципи цілепокладання та самомотивацію тих, хто навчається. Майбутній магістр природничої галузі повинен володіти високим ступенем самостійності, відповідальності, готовністю поповнювати свої знання протягом всього життя, його конкурентноздатність повинна визначатися не лише ступенем адаптації до сфери професійної діяльності, здатністю до перенавчання та оволодіння суміжними професіями, а й готовністю до неперервного саморозвитку та самоосвіти.

Магістерська освіта природничого спрямування $\epsilon$ процесом і результатом опанування здобувачем освіти програми підготовки магістра, що спрямована на розвиток професійних, особистісних якостей та дослідницької компетентності в сфері професійної діяльності, які дозволять розв'язувати науковотехнологічні задачі та проблеми інноваційного характеру в галузі природничих наук та здійснювати в цих сферах науково-дослідну діяльність.

Визначимо основні фактори, що обумовлюють необхідність впровадження елементів ДН до соціально-гуманітарної підготовки магістрів природничих спеціальностей.

По-перше, в умовах магістратури змінюється сам стиль навчання: значна частина навчального часу проходить не в аудиторії з викладачем, а в режимі самостійної роботи.

Аналіз змісту соціально-гуманітарної складової навчальних планів підготовки магістрів природничого спрямування провідних 3ВО, демонструють, що існує реальний дефіцит навчального часу на вивчення дисциплін соціально-гуманітарного спрямування. Тижневе навчальне навантаження для соціально-гуманітарних дисциплін складає 1-2 години, що складає 8-11\% загального навантаження.

Цілком очевидно, що в умовах постійного збільшення обсягу нової інформації 3 соціальногуманітарних знань і обмеження часу на іiі засвоєння, ключова роль у формуванні соціальногуманітарної компетентності майбутнього магістра природничої галузі відводиться самостійній роботі.

I тут варто зазначити, що самостійна робота студентів в умовах ДН має ряд принципових переваг та відмінностей від самостійної роботи під час традиційного навчання:

- по-перше, самостійна робота в умовах ДН є абсолютно керованою викладачем оскільки на кожному іiі етапі ставляться конкретні мета та завдання, а також постійно контролюється їх виконання. За необхідності надаються оперативні консультації та допомога з боку викладача, як в режимі online так і в 
режимі offline (Інтернет, електронна пошта, скайп, телефон, сучасні месенджери: Viber, Telegram, WhatsApp та ін.);

- по-друге, самостійна робота здійснюється за індивідуальним планом, у зручному для здобувача освіти місці, темпі, послідовності;

- по-третє, навчально-методичне забезпечення самостійної роботи не обмежується лише методичними рекомендаціями, переліком літературних джерел та тем для опанування, а здійснюється за допомогою спеціалізованих дистанційних навчальних комплексів, курсів та інших комп'ютерних засобів навчання;

- по-четверте, здобувач вищої освіти повинен володіти методами планування та організації самостійної роботи 3 навчальним матеріалом в системі ДН, мати навички самоосвіти та навички роботи 3 комп'ютером і мережею Інтернет.

Відмінні показники самостійної роботи при дистанційному та традиційному навчанні наведені у табл. 1 .

Таблиця 1 - Особливості організації самостійної роботи в умовах традиційної та дистанційної форм навчання

\begin{tabular}{|c|c|c|}
\hline Показник & $\begin{array}{c}\text { Традиційне } \\
\text { навчання }\end{array}$ & $\begin{array}{c}\text { Дистанційне } \\
\text { навчання }\end{array}$ \\
\hline $\begin{array}{c}\text { Методи } \\
\text { навчання }\end{array}$ & $\begin{array}{l}\text { Пояснювально- } \\
\text { ілюстративний, } \\
\text { репродуктивний }\end{array}$ & $\begin{array}{l}\text { Інформаційно- } \\
\text { пошуковий, } \\
\text { дослідницький }\end{array}$ \\
\hline Зміст навчання & $\begin{array}{c}\text { Статичний } \\
\text { характер }\end{array}$ & $\begin{array}{c}\text { Динамічний } \\
\text { характер }\end{array}$ \\
\hline $\begin{array}{c}\text { Доступ } \\
\text { до навчальних } \\
\text { матеріалів }\end{array}$ & Обмежений & Необмежений \\
\hline $\begin{array}{c}\text { Статус науково- } \\
\text { педагогічного } \\
\text { працівника }\end{array}$ & $\begin{array}{c}\text { НПП виступає } \\
\text { основним носі- } \\
\epsilon м \text { навчальної } \\
\text { інформації }\end{array}$ & $\begin{array}{l}\text { НПП виступає } \\
\text { помічником, } \\
\text { консультантом }\end{array}$ \\
\hline $\begin{array}{c}\text { Статус } \\
\text { здобувача } \\
\text { вищої освіти }\end{array}$ & $\begin{array}{c}\text { Здобувач } \\
\text { пасивно } \\
\text { накопичує } \\
\text { знання }\end{array}$ & $\begin{array}{c}\text { Здобувач } \\
\text { активний } \\
\text { учасник } \\
\text { освітнього } \\
\text { процесу }\end{array}$ \\
\hline $\begin{array}{c}\text { Інтерактивність } \\
\text { навчання }\end{array}$ & Середня & Висока \\
\hline $\begin{array}{c}\text { Індивідуалізація } \\
\text { навчання }\end{array}$ & Низька & Висока \\
\hline
\end{tabular}

Отже, якісно структурована та керована дистанційна самостійна робота під час соціальногуманітарної підготовки в умовах дефіциту навчального часу, сприятиме формуванню соціальногуманітарної компетентності у майбутніх магістрів природничої галузі.

По-друге, поглиблюється інтеграція навчання 3 науково-дослідною діяльністю (НДД). Замість традиційного репродукування знань майбутні магістри залучаються до процесу пошуку та відкриття нових знань.

Під час професійної підготовки в умовах магістратури майбутні фахівці природничої галузі вико- нують цілу низку навчально-дослідних та науководослідних робіт: курсові роботи, доповіді на конференціях, підготовка рефератів, звіти за результатами лабораторних робіт, наукові повідомлення на спеціальних семінарах, написання наукових статей, виконання випускного магістерського дослідження. Кожен 3 видів вищеназваних робіт відрізняється один від одного обсягом та рівнем складності. Одні види робіт (доповіді, реферати, наукові повідомлення) містять лише огляд наукової літератури і періодики та власну критичну оцінку, інші види робіт (лабораторні звіти, курсові роботи, магістерські дослідження) є результатом власної науково-дослідної роботи здобувача освіти.

Вчені Л. Кулик та А. Ткаченко [5], досліджуючи формування умінь та навичок НДД студентівфізиків, визначають, що основною метою НДД у ЗВО є створення умов для всебічного розвитку i реалізації творчого потенціалу студента.

С. Дембицька та О. Кобилянський [6] наголошують, що НДД студентів $є$ важливим чинником підвищення ефективної професійної підготовки майбутнього фахівця у ЗВО тому, що передбачає індивідуалізацію навчання, дає змогу реалізовувати особистісно-орієнтоване навчання, розширює обсяг знань, умінь, навичок, загальнокультурних та професійних компетентностей, сприяє формуванню активності, ініціативи, допитливості, розвиває творче мислення, спонукає до самостійних пошуків.

Ми погоджуємося із вченими, та вважаємо, що для успішної реалізації завдань НДД магістри природничих спеціальностей повинні мати міцну соціально-гуманітарну підготовку. Наприклад, для презентації на науковому семінарі чи конференції своїх наукових напрацювань, майбутній магістр повинен здійснити вибір теми та напрям дослідження; проаналізувати, систематизувати та узагальнити сучасну наукову літературу в галузі дослідження; знайти оптимальні методи, для здійснення обраного дослідження; спланувати, виконати та проаналізувати результати дослідження; сформулювати висновки та узагальнення; оперувати понятійним апаратом дослідження. I саме якісна соціально-гуманітарна підготовка, на нашу думкою, $є$ запорукою успішної реалізації цього завдання. Наші спостереження, бесіди 3 науково-педагогічними працівниками та майбутніми магістрами природничого спрямування, відвідування наукових студентських конференцій, семінарів, засідань екзаменаційних комісій із захисту дипломних робіт свідчать про те, що значній частині майбутніх магістрів притаманні одні й ті самі помилки. За наявності відмінних результатів науково-дослідної роботи професійної - природничої тематики, спостерігається відсутність навичок презентації результатів власного дослідження для аудиторії фахівців та не фахівців, відсутність навичок створення мультимедійних презентацій, слабкі комунікативні здібності, невміння вести наукову дискусію та відстоювати власні ідеї, низький рівень володіння науковою термінологією.

Вирішенням вищеназваних проблем може стати застосування ДН під час соціально-гуманітарної підготовки магістрів природничих спеціальностей. 
Адже у системі ДН зміст навчального матеріалу можна варіювати 3 урахуванням потреб здобувачів освіти щодо їхньої майбутньої професійної діяльності.

По-третє, змінюється спосіб життя самих здобувачів освіти: поширеною ситуацією серед магістрів природничих спеціальностей $є$ суміщення навчання і роботи. I цей фактор відіграє вагому роль при впровадженні ДН у процес фахової підготовки магістрів природничого спрямування.

Одним з важливих аспектів магістерської освіти $\epsilon$ розуміння іiі, як освіти дорослих. Традиційно навчання дорослих розглядається як підвищення кваліфікації, оволодіння новою професією та ін. Тому необхідно враховувати активність, прагнення до самостійної роботи та досвід здобувача освіти магістранта. Задля успішного впровадження елементів ДН у процес підготовки магістрів природничих спеціальностей необхідно враховувати, що студенти вступають на навчання найчастіше у віці 21-23 років. Психологи визначають цей вік як період «ранньої дорослості» [7]. Характерною особливістю цього періоду є те, що людина прагне до самостійного, незалежного життя, усвідомлює себе дорослою і рівноправною. Відбувається включення особистості в усі види соціальної активності та оволодіння багатьма соціальними ролями.

За твердженням Ш. Бюлера [8], протягом цієї фази вікового розвитку (до 25 років) людина, як правило знаходить своє призначення або вже має постійну професійну діяльність. При цьому особистість перебуває або на фазі адепта, коли вибір професії вже зроблено і починається (або продовжується) процес їі освоєння, або на фазі адаптації, тобто оволодіння і прийняття норм професійної діяльності та професійного спілкування, розуміння сенсу професії і своєї причетності до неї.

Отже, здобувачі освіти - магістранти є фахівцями, що мають базову або повну вищу освіту, певний професійний досвід, перебувають у віці періоду «досягнень», коли особистість використовує інтелектуальні здібності задля побудови кар'єри та визначення стилю життя вже маючи певний соціальний навчальний, професійний досвід. Варто також зазначити, що у молодому віці (20-25 років) людина $\epsilon$ максимально працездатною, витримує найбільші фізичні і психічні навантаження, здатна оволодівати складними засобами інтелектуальної діяльності. Це означає, що молоді люди здатні органічно поєднувати дистанційне навчання з роботою, обираючи зручне місце, режим, темп і розклад опанування навчального матеріалу. Тому використання елементів ДН під час професійної підготовки, соціальногуманітарної зокрема, вирішує питання реалізації права майбутніх магістрів на трудову діяльність.

Вартим нашої уваги є і той факт, що стрімко набирає обертів участь здобувачів освіти-магістрантів в реалізації спільних освітніх програм українських та закордонних 3ВО - академічна мобільність, особливо це стосується магістрів природничих спеціальностей. Академічна мобільність $є$ інтеграційним процесом у сфері освіти, що надає можливість студентам, аспірантам, науково-педагогічним та педа- гогічним працівникам приймати участь в різноманітних освітніх або науково-дослідницьких програмax.

Як приклад, у Харківському національному університеті імені В.Н. Каразіна у період з 2011 по 2018 рік кількість студентів та аспірантів, які реалізували право на академічну мобільність у вигляді навчання, наукового та мовного стажування, склала 2079 осіб, які виїжджали до 66 країн [9]. Найбільша кількість цих відряджень була на природничих та технічних факультетах, а саме на факультетах: геології, географії, рекреації і туризму; математики i інформатики; фізичному; фізико-технічному; хімічному. Зокрема, на фізико-технічному факультеті за означений період реалізували право на академічну мобільність 50 студентів магістратури (навчання за програмами підготовки магістра, наукове стажування, участь у спільних науково-дослідних проектах, участь у роботі міжнародних наукових шкіл, конференцій, тренінгових семінарів), які виїжджали до університетів 16 країн світу.

Використання ДН при опануванні соціальногуманітарних дисциплін полегшує корекцію індивідуальних навчальних планів для майбутніх магістрів природничих спеціальностей, які із різних причин (участь у турнірах, олімпіадах, конференціях; змаганнях; хвороби) не відвідують заняття. Повсякденною практикою ЗВО, що готують магістрів природничої галузі, стало залучення студентів магістратури до роботи у якості членів журі на учнівських олімпіадах та турнірах різного рівня (районних, міських, обласних та всеукраїнських).

При моделюванні та впровадженні в освітній процес підготовки магістрів природничих спеціальностей елементів ДН варто враховувати те, що опанування магістерської програми підготовки має стати для майбутнього фахівця природничої галузі фундаментом для подальшого навчання та удосконалення протягом всього життя. Сформовані під час навчання в магістратурі знання, уміння, компетентності та світоглядна позиція дадуть можливість молодому фахівцю природничої галузі допомагати іншим в отриманні знань, стати лідером або керівником у своїй професійній сфері діяльності. I соціально-гуманітарні знання йому просто необхідні.

Цікавими в контексті нашого дослідження видаються ідеї, що представлені в роботі колективу авторів [10], які доводять особливу актуальність соціально-гуманітарної складової у процесі підготовки магістрів природничих спеціальностей, що передбачає оптимізацію відносин викладач-студент та суб'єктний підхід до навчальної діяльності студентів. Ці аспекти важливо враховувати при організації соціально-гуманітарної підготовки майбутніх магістрів природничих спеціальностей в умовах дистанційного навчання. Магістерська освіта повинна створювати умови для розвитку у майбутніх фахівців природничої галузі рефлексії у діяльності та спілкуванні, орієнтувати на найкращі зразки професійної майстерності, стимулювати магістрантів для оволодіння вершинами цієї майстерності. I саме акмеологічний підхід до проектування дистанційно- 
го освітнього процесу і націлено на реалізацію якісної підготовки магістрів природничої галузі.

Акмеологічний підхід - це інтеграція предметного, педагогічного та психологічного знання з урахування специфічних особливостей акмеології розвитку особистості майбутнього фахівця. С точки зору даного підходу дистанційний освітній процес соціально-гуманітарної підготовки магістрів природничого спрямування повинен по-перше, мати максимально самостійний та індивідуальний характер; подруге, мати дослідницьку направленість і по-третє, бути особистісно-орієнтованим.

В контексті нашого дослідження ми виділили такі основні принципи побудови та впровадження елементів ДН у процес соціально-гуманітарної підготовки магістрів природничих спеціальностей:

- вільний вибір майбутнім магістром (у рамках дисциплін соціально-гуманітарної підготовки) професійно-освітньої траєкторії, яка погоджується 3 науково-педагогічним працівником, що дистанційно викладає дисципліни;

- створення умов для самореалізації майбутнього магістра у творчій та дослідницькій діяльності через можливість вибору індивідуальних або групових завдань, що передбачають різний ступінь залучення магістра у дослідження проблеми або іiі фрагментів;

- актуалізація і врахування соціальнопрофесійного досвіду майбутнього магістра при побудові навчального матеріалу у дистанційному середовищі (його відношення до майбутньої професійної діяльності, усвідомлення необхідності здобуття міцних соціально-гуманітарних знань для професійної діяльності, наявність базових соціально-гуманітарних знань, досвіду та ін.).

Успішній реалізації вищеназваних принципів сприятимуть, на нашу думку, спеціально розроблені завдання для самостійної роботи у дистанційному навчальному середовищі. Ці завдання мають бути направлені на розвиток та формування умінь бачити та розуміти проблему, умінь будувати гіпотези, умінь спостерігати, умінь проводити експерименти, умінь доводити свою точку зору, умінь представити результати свого дослідження для інших учасників освітнього процесу.

Під час експериментального дослідження нами використовувалися в освітньому процесі підготовки магістрів під час вивчення дисциплін соціальногуманітарного циклу такі елементи дистанційних навчальних курсів: електронні лекції; відео файли; індивідуальні завдання творчого, інформаційнопошукового характеру; систему поточного та підсумкового тестового контролю.

Задля реалізації цього завдання нами було впроваджено в освітній процес підготовки магістрів спеціальності 105 «Прикладна фізика та наноматеріали» денної форми навчання з дисциплін циклу загальної підготовки «Чинники успішного працевлаштування за фахом» та «Педагогіка вищої школи» використання елементів дистанційних навчальних курсів. Вищеназвані курси було розроблено в системі ДН Moodle 3 використанням навчально-методичних комплексів цих дисциплін. Створені дистанційні курси мають інтегрований характер і структурно складаються 3 функціонально-узгоджених блоків: інструктивного, навчально-інформаційного, комунікативного та контрольного [11].

Інструктивний блок містить: загальну інформацію про курс (що вивчає дисципліна, мета та завдання курсу, актуальність та практична значущість, зв'язок 3 іншими предметами обраної спеціальності тощо); навчальну програму курсу; рекомендації щодо організації процесу навчання; навчальний план та графік вивчення дисципліни: назви тем та рекомендована послідовність їх вивчення; орієнтовна кількість годин на вивчення кожної теми курсу; теми дискусій (з переліком основних питань) та час їх проведення. Інструктивний блок також забезпечує реєстрацію студентів та збереження вхідних даних про них;

Навчально-інформаційний блок містить системний курс лекцій, завдань, практичних робіт, відео файли, інформаційні посилання, додаткову літературу в електронному вигляді. Тобто $є$ системою інформаційного наповнення дистанційного курсу;

Комунікативний блок це система інтерактивного спілкування між викладачем та студентами та студентами між собою. Комунікативна діяльність студентів під час дистанційного навчання триває постійно й здійснюється за допомогою телеконференцій, електронної пошти, дискусій, чатів тощо. Спілкування може відбуватись і в синхронному, і в асинхронному режимі.

Контрольний блок містить механізми тестування, перевірки та оцінювання знань студентів, які мають і проміжний, і підсумковий характер. При створенні дистанційних навчальних курсів ми орієнтувалися на актуальність навчального матеріалу, різноманітність форм його подання: при побудові лекцій ми використовували не лише текст, а й мультимедійні презентації, ілюстрації, відео файли тощо.

ВИСНОВКИ. Підсумовуючи зазначимо, що впровадження елементів дистанційного навчання в процес соціально-гуманітарної підготовки магістрів природничих спеціальностей сприяє індивідуалізації навчання та ефективності самостійної роботи, дозволяє розширити можливості студентів у засвоєнні освітніх програм та взаємодії з викладачем незалежно від місця їхнього перебування та розподілу часу, дає можливість підвищити мотивацію до навчання студентів, активізувати навчально-пізнавальну діяльність майбутніх магістрів та розвиток творчих здібностей i, як результат - покращити якість навчання.

Робота над розвитком та формуванням умінь бачити та розуміти проблему, умінь будувати гіпотези, умінь спостерігати, умінь проводити експерименти, умінь доводити свою точку зору, умінь представити результати свого дослідження для інших учасників освітнього процесу в рамках дистанційної соціально-гуманітарної підготовки, належний рівень засвоєння фундаментальних положень теоретичної складової підготовки, підкріплений необхідними практичними навичками є тим вагомим підгрунтям, що може забезпечити формування достатнього рівня компетентностей та цілісної системи умінь майбутнього магістра природничого спрямування для успішного завершення освітньої програми підготовки 
та створення якісних передумов для побудови успішної професійної кар'єри.

\section{ЛІТЕРАТУРА}

1. Шабанов А. Г. О подготовке педагогов к работе в системе дистанцинного обучения. Инноващиии в образовании. 2004. № 4. С. 69-74.

2. Берест Т. М., Берест В. П. Використання елементів дистанційного навчання в роботі зі студентами стаціонару. Дистанційна освіта Украӥни-2013. Інформаційне освітне середовище у системі дистанційного навчання в закладах освіти: інноваційні та психологічні аспекти : збірник наукових прачь Харківського національного автомобільногодорожнього. університету. Харків, 2013. С. 17-22.

3. Положення про дистанційне навчання: Наказ Міністерства освіти і науки України від 25.04.2013 № 466 URL: https://zakon.rada.gov.ua/ laws/show/z0703-13 (дата звернення 15.12.2018).

4. Васильєв А., Коровайченко Ю. Дистанційне навчання - це сучасно. Освіта України. 2013. 17 черв. (№ 24). С. 6.

5. Кулик Л. О. Формування умінь та навичок науково-дослідної діяльності студентів напряму підготовки «Фізика». Вісник Чернігівського національного педагогічного університету. Педагогічні науки. 2013. Вип. 109. С. 190-192.

6. Дембицька Н. М., Кобилянський О. В. Організація науково-дослідної роботи студентів в процесі вивчення дисципліни «Охорона праці». Збірник наукових праць Кам'янець-Подільського національного університету імені Івана Огієнка, Серія педагогічна. 2015. № 21. С. 191-194.

7. Пиралова О. Ф. Особенности обучения в магистратуре современныхВУЗов. Успехи современного естествознания. 2010. № 5. C. 78-80. - URL: https://www.natural-sciences.ru/ru/article/view?id=8125 (дата звернення 11.02.2019).

8. Логинова Н. А. Развитие личности и ее жизненный путь. Принциип развития в психологи / Под ред. Л. И. Анцыферовой. Москва, Наука, 1978. С. $156-172$.

9. Звіт ректора Харківського національного університету імені В.Н. Каразіна Бакірова В.С. за 2018 рік URL: http://www.univer.kharkov.ua/ docs/work /zvit_rektora_2018.pdf (дата звернення 15.03.2019).

10. Гурина Д. Л., Садина С. С., Сироткин Н. А. Физики и лирики: новации вобразовании и универсальная личность. Известия высших учебных заведений. Серия «Гуманитарные науки». 2010. Том 1. Вып. 2. С. 150-153.

11. Попенко Н. В. Досвід використання елементів дистанційного навчання при підготовці магістрів денної форми навчання. Дистанщійне навчання старт із сьогодення в майбутне : збірник науковометодичних праць II Всеукраїнської науковопрактичної конференції з міжнародною участю, (м. Харків, 19 трав. 2016 р.). Харків, 2016. С. 122127.

\section{FEATURES OF DISTANCE LEARNING ELEMENTS IMPLEMENTATION IN THE PROCESS OF SOCIAL AND HUMANITARIAN TRAINING OF MASTERS OF NATURAL SPECIALTIES}

\section{N. Popenko}

Kremenchuk Mykhailo Ostrohradskyi National University

vul. Pershotravneva, 20,39600, Kremenchuk, Ukraine. E-mail:popenko_nata@ukr.net

Purpose. The article is dedicated to the substantiation of the distance learning elements features implementation in the educational process of Masters of Natural Sciences. Methodology. The research is carried out a theoretical analysis of regulatory and educational research literature on distance education; the main factors determining the necessity of introduction of distance education in the process of social and humanitarian training of Masters of Natural Science are determined. Results. The study of the professional training content of the Masters of Natural Sciences indicates the existence of a shortage of study time for the study of social and humanitarian disciplines that are necessary for the future specialist for successful professional activities. Therefore, we give the key role in shaping the social and humanitarian competence of future Masters of Natural Sciences in a qualitatively structured and managed distance independent work, because in the system of distance education the content of the teaching material can be varied in the light of the needs of education providers. Originality. Master's education as an adult education should create the conditions for the reflection in the future professionals to work and communicate, and focus on the best examples of professional skills. The use of an acmeological approach to the design of a distance educational process and is aimed at the implementation of quality training. The arguments given in the article allowed to highlight the basic principles of constructing and implementing the elements of distance education courses in the educational process of Masters of Natural Sciences, namely: the future Master's free choice of professional educational trajectory; creation of conditions for self-realization in creative and research activity; updating and taking into account the social and professional experience of the future Master's Degree. Practical value.The facts of our study indicate the need to introduce the elements of the distance education courses in social and humanitarian disciplines developed on the basis of the Moodle platform. Established distance courses are integrated and structurally consist of functionally-agreed blocks: instructional, educational, informational, communicative and controlling ones. Conclusions. The work on the formation of social and humanitarian competence in the conditions of distance education, the proper level of mastering the fundamental provisions of the training theoretical component supported by the necessary practical skills is the basis for the formation of a coherent system of knowledge, skills and competences of the future Master of Natural Sciences for the construction of a successful professional career.

Key words: educational process, distance learning, Masters of Natural Sciences, social and humanitarian training. 


\section{REFERENCE}

1. Shabanov, A. G. (2004), "O podgotovke pedagogov $k$ rabote $v$ sisteme distantsinnogo obucheniya" [About the training of teachers to work in the distance learning system], Innovatsii v obrazovanii [Innovations in education], No 4, pp. 69-74.

2. Berest, T. M. (2013), "Vikoristannya elementiv distancijnogo navchannya $v$ roboti $z i$ studentami stacionaru" [Using the elements of distance learning in working with full-time students], Distancijna osvita Ukrayini-2013. Informacijne osvitnye seredovishe $u$ sistemi distancijnogo navchannya $v$ zakladah osviti: innovacijni ta psihologichni aspekti, Zbirnyk naukovykh prats Harkivskoho nacionalnoho avtomobilnodorozhnoho universiteta [Distance education of Ukraine-2013. Information educational environment in the system of distance learning in educational institutions: innovative and psychological aspects, Collection of scientific works of Kharkiv National Automobile and Highway University], pp. 17-22.

3. Polozhennya pro distancijne navchannya (2013) [Regulations on distance learning], Nakaz Ministerstva osviti i nauki Ukraiini vid 25.04.2013 № 466 [Order of the Ministry of Education and Science of Ukraine dated April 25, 2013No 466] - URL: http://www.udec.ntukpi.kiev.ua/udec.nsf.

4. Vasilyev, A., Korovajchenko, Yu. (2013), "Distancijne navchannya - ce suchasno" [Distance learning is modern], Gazeta "Osvita Ukrayini» [The newspaper "Education of Ukraine"], No 24.

5. Kulik, L. O., Tkachenko, L. V. (2013), "Formuvannya umin ta navichok naukovo-doslidnoyi diyalnosti studentiv napryamu pidgotovki "Fizika" [Formation of Skills and Abilities of Students' Research Activities in the Field of Physics], Visnik Chernigivskogo nacionalnogo pedagogichnogo universitetu. Pedagogichni nauk. [Bulletin of Chernihiv National Pedagogical University. Pedagogical sciences], No 109, pp.190-192, URL: http://nbuv.gov.ua/UJRN/VchdpuP_2013_109_48.

6. Dembicka, N. M., Kobilyanskij, O. V. (2015), "Organizaciya naukovo-doslidnoyi roboti studentiv $v$ procesi vivchennya disciplini "Ohorona praci" [Organization of research work of students in the course of studying the discipline "Labor Protection"], Zbirnik naukovih prac Kam'yanec-Podilskogo nacionalnogo universitetu imeni Ivana Ogiyenka, Seriya pedagogichna [Collection of scientific works of the Kamenets-Podolsky National University named after Ivan Ogienko, Pedagogical series], 2015, No 21, pp. 191-194.
7. Piralova, O. F. (2010), “Osobennosti obucheniya $v$ magistrature sovremennih vuzov" [Features of training in the magistracy of modern universities], Uspehi sovremennogo estestvoznaniya [Successes of modern science], No 5, pp. 78-80, URL: https://www.natural-

sciences.ru/ru/article/view $\mathrm{id}=8125$.

8. Lohinova, N. A. (1978), "Razvitie lichnosti i ee zhiznennyj put" [Personality development and its life course], Princip razvitiya $v$ psihologii [Principle of development in psychology], edited by Ancyferova L.I., Moscow, Nauka Publishing House, pp. 156-172.

9. "Zvit rektora Harkivskogo nacionalnogo universitetu imeni V.N. Karazina Bakirova V.S. za 2018 rik" [Report of the rector of the V.N. Kharkiv National University Bakirov V.S. for 2018] URL: http://www.univer.kharkov.ua/docs/work/zvit_rek tora_2018.pdf.

10. Gurina, D. L., Sadina, S. S., Sirotkin, N. A. (2010), "Fiziki $i$ liriki: novacii $v$ obrazovanii $i$ universalnaya lichnost" [Physics and Lyrics: Innovations in Education and the Universal Person], Izvestiya vysshih uchebnyh zavedenij. Seriya "Gumanitarnye nauki" [Proceedings of higher educational institutions. Series "Humanities"], No 2, pp. 150-153.

11. Popenko, N. V. (2016), "Dosvid vikoristannya elementiv distancijnogo navchannya pri pidgotovci magistriv dennoyi formi navchannya" [The experience of using the elements of distance learning in the preparation of masters of full-time education], Distancijne navchannya - start iz sogodennya $v$ majbutnye: zbirnik naukovo-metodichnih prac II Vseukrayinskoyi naukovo-praktichnoyi konferenciyi $z$ mizhnarodnoyu uchastyu, [Distance Learning - Start From Present to the Future: A Collection of Scientific and Methodical Works of the 2nd All-Ukrainian Scientific and Practical Conference with International Participation], pp. 122-127.

Стаття надійшла 01.04.2019. 